Сања Корићанац

Министарство одбране

Републике Србије

sanjakoricanac2000@yahoo.co.uk
159.964 .26

https://doi.org/10.18485/ai_lik.2019.5.8.2

Оригинални научни рад

\title{
ЈУНГИЈАНСКА ПСИХОАНАЛИТИЧКА ШКОЛА У ФОЛКЛОРИСТИЦИ: МОТИВИ УРОБОРОСА И ВЕЛИКЕ МАЈКЕ
}

Присталице психоаналитичке школе јунгијанске оријентације у фолклористици проналазе садржаје који би могли да поткрепе теорије о континууму и универзалности људске природе на онтогенетском и филогенетском плану. Настојали смо да расветлимо мотиве уробороса и Велике мајке представљајући поставке поборника овог правца који су тумачили митове, народне приче и слике у функцији развоја личности преко појмова који одређују школу К. Г. Јунга, а то су: лично и колективно несвесно, трансперсонално, симболичност, архетипови, синхроницитет, двојност, анима и анимус, индивидуација и интроверзија.

Кључне речи: Јунг, психоанализа, Велика мајка, уроборос, фолклор, несвесно, симболичност, трансперсонално, индивидуација.

\section{1. Порекло базичних Јунгових појмова у вези са фолклорним садржајима}

Фолклор је за Дандиса (Dundes 2007: 55) огледало културе, аутобиографска етнографија коју чине митови, народне приче и песме, легенде, пословице и друге народне умотворине. Фолклор учествује у обликовању културалних норми и нуди уточиште од стега које може наметати постојећа култура (291-292). Дандис (56) издваја као један од циљева проучавања фолклора утврђивање универзалних начела 
људског постојања у оквиру различитих заједница, а овакав холистички прилаз појавама здушно негују присталице учења Карла Густава Јунга. Психоаналитички приступ анализирању фолклора Дандис (273) сумира као сагледавање психичког развоја појединца, његових страхова, амбиваленције, пројекција и тенденције за самоостваривањем у светлу симболичких односа и обичаја унутар друштвене групе којој припада.

Јунгов отац је био протестантски свештеник (Wehr 1987: 9), те мора да Јунгово инсистирање на складу човекове индивидуалности и повезаности са божанским има везе са одрастањем у протестантској породици. Јунгово увиђање да лично несвесно није довољно да се разјасни суштина човека нагонило га је да изучава различите културе у којима је открио одјеке дубље равни океанског осећања повезаности. Клаф (Clough 2013) сведочи да је Јунг био под јаким утицајем континенталне филозофије када каже да је Јунг говорио да се ослања на Кантову Крийику зgравоі разума, стога је вероватно и идеја о колекииивном несвесном као архаичној психичкој наслази искуства које се преноси из генерације у генерацију доведена у везу са надличним. У Кантовом маниру је и Јунгов појам архетипске представе која је заправо слика, субјективни приказ онога што је у човеку већ убележено. Јунг (2005: 51-53) за ове универзалне форме у психи каже да их није он први открио јер их истраживачи митологије називају мотиивима, психолози за њих користе Леви-Брилов

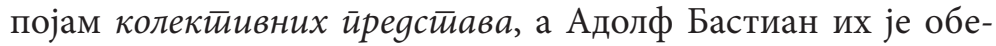

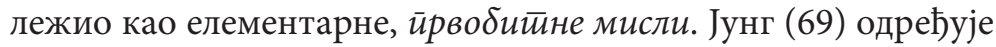
прототипску природу архетипова када корене тог истоветног заједничког искуства открива у општем паралелизму митолошких мотива. Холбек (1987: 294) порекло симбола проналази у тежњи несвесног да сликама искаже своје увиде. Сам Јунг (Jung \& Neumann 1989: xv) дефинише архетипове или примордијалне слике као елементе структуре колективног несвесног који су сликовни облици нагона јер се несвесно свесном уму открива кроз призоре који, попут снова и фантазија, иницирају процес свесних реакција и асимилација. Јунгова сарадница Јакобијева (Jacobi 1959) разјашњава да неосвешћено значење симбола захтева активније мисаоно 
ангажовање појединца. Ако ово укључивање изостане, симбол ће се поново јавити у снажнијем и претећем облику како би се остварио план инguвиgуације - дуготрајног процеса духовног сазревања појединца ради открића сопствене хармоничне целовитости.

\section{2. Основне поставке, приступ и представници јунгијанске школе}

Јунг (1989: xiv) сврсисходним сматра рад Нојмана који кроз корпус митова заснива јединствену историју еволуције свесности на појмовима матријархалног симболизма и уробороса као симбола у психологији алхемије. За Јунга је најважнији онај аспект ових проучавања који је посвећен стицању нових сазнања из психологије несвесног и он је свестан да овакав приступ намеће ограничења, стога Јунг личном јеgначином назива чинилац пристрасности који боји виђење сваког истраживача, али га и брани истичући да је ова врста посвећености од највеће важности у психологији. Јунг са Керењијем 1941. године објављује студију о митским архетиповима, а 1943. и 1948. излазе две студије о бајкама које су од тада постале предмет истраживања на његовом Институту у Цириху. У првом делу студије из 1943. наилазимо на тумачење бајке браће Грим Geist im Glas која је верзија приче о духу из боце из арапске традиције. Холбек (1987: 301) примећује да је у анализи ове бајке Јунг посветио пажњу неким појавама око којих ће се развити тумачења фолклорних казивања јунгијанске оријентације: мотиви шуме и мора који представљају несвесно, али и мотив великог храста у сред шуме који упућује на прототип сопства као симбола порекла и циља индивидуације јунака чија је личност још увек непросвећена сазнањем о унутарњој тајни која тежи да се ослободи духовним уздигнућем из корена физичког постојања. Јунг (2015: 65-66) је критички настројен према фаворизовању материјалистичких теорија деветнаестог века које се своде на физиологију нагона. Овакав Јунгов приступ се битно разликује од става Фројдове школе која никада не 
чита бајку као критички коментар постојећег друштва или као модел за развој појединца. Јунг (2005: 59) не одобрава приземност Фројдовог трагања за недоличном жељом, пре се приклања становишту феноменологије по коме је архетип услов могућности психичког збивања. Узимајући за примере грчки мит о Херакловом пореклу од људских и божанских родитеља и египатски пандан по коме је фараон по својој природи људско и божанско биће, а што се види по зидовима старих египатских породилишта где је осликано фараоново друго божанско зачеће са рађањем, Јунг (53-54) указује да се са личним планом овде преплиће не-лични мотив о две мајке који је однекуд добро познат човеку.

Холбек (1987: 292) у делима истраживача симболизма и компаративне митологије Вилхелма Лаиблина, Џозефа Кембела и Маргерит Лефлер-Делашо уочава зачетке јунгијанског приступа у изучавању фолклора чији су најпознатији заступници Ерих Нојман, Мари-Луиз фон Франц, Хедвиг фон Бајт, Бруно Бетелхајм и Ханс Дикман. Нојман (1989: xvii) признаје да се он бави митом искључиво на основу свог искуства из психотерапеутске праксе која изучава дубљу психичку позадину савременог човека. Бетелхајм (1979: 19-21) држи да су бајке погодне за пренос поруке јер би рационално упакована мисао збунила примаоца. Бетелхајм се бави главним проблемом одрастања - превазилажењем нарцистичких разочарања попут супарништва, едипалних дилема и напуштања зависности од родитеља (137). По њему, бајке могу помоћи човеку да интегрише своје несвесно Ја (128), да прихвати начело реалности (47), да пронађе извор безбедности у себи (31) и да успостави истински задовољавајућу везу са другим (25).

Мари-Луиз фон Франц (2011: 41-44) полази од теорије укорењености наших идеја у архетипским представама које се формирају по принципу различитих пројекција. Повезујући је са кинеским, интуитивним моделом објашњавања и предвиђања који је близак спознајама савремене физике, фон Францова (1980: 10-13) означава Јунгову теорију синхроницитета као акаузалну јер Јунг (2016) инсистира на постојању двојних, скоро опречних феномена у једном 
ентитету. Јунгијански приступ доноси велико психолошко откриће да магијски ритуали делују због реалности душе, а не због реалности света. Нојман (1989: 209-210) тврди да просвећени рационализам погрешно схвата магију, молитву, колективне идеје и снове као илузорне. По њему, промена у субјекту изазива последицу која постаје објективна, а само откриће објективног, спољашњег света је последица човекових свесних настојања.

\section{3. Архетипске фазе развоја свести кроз примере из фолклора из визуре јунгијанске школе}

Нојман и Јунг (1989: xv) одређују архетипске фазе тока развоја свести претпостављајући да се ове слике по аналогији најприближније могу упоредити са митолошким типовима. Јунг (2015: 163-164) верује да се оне наслеђују баш као и други морфолошки делови људског тела у оквиру опште људске психе. Он упозорава да занемаривање архетипских чинилаца психе без изузетка изазива неуротичне и чак психотичне поремећаје у виду одређене једностраности при обликовању садржаја свести (165). Нојман (1989: xvi) пише о свесности Ега која еволуира пролазећи кроз низ вечитих слика према којима се однос Ега стално мења. Фон Францова (1997: 65-66) каже да се динамика развоја Ега ретко представља као кристал или дијамант, концепт Ега је по њој ближи таоистичкој филозофији сталности промене која се у фолклору приказује преко употребе плеса и ритмичких радњи који сведоче о пристајању на правила заједнице. Плес се повезује са протицањем времена и фон Францова (68) објашњава да освешћивањем себе човек одустаје од статичности и прихвата еластичнији став према коме за све постоје посебно време и место. Фон Бајтова (von Beit 1956) сматра да бајке чине спој свесног ума са моћима несвесног, а тај концепт подсећа на оно што Лакан касније назива уйаgом реал-

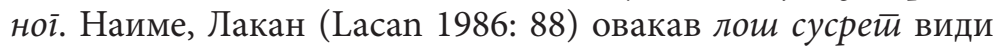
као центар кастрационе тескобе који је пресудан за сваки концепт развоја. 
Нојман (1989: xx-xxii) примећује одраз трансперсоналне међузависности колективног и појединачног у раној историји колективног њеном одређеношћу примордијалним сликама чије се пројекције јављују у виду моћних сила као што су богови, духови или демони и који постају предмети обожавања. Психичким развојем управљају симболи, идеалне форме и психичке категорије који функционишу по принципима аналогије, пројекције итд. Узрок настанка симбола Јунг (2015: 189) доводи у везу са кризом која потиче од губитка повезаности са дубљим значењем која за последицу може имати појаву секундарне иеерсонализаиије која подразумева да примарно трансперсонални садржаји временом постају лични и нужни за очување структуре личности будући да се садржаји који су првобитно имали облик трансперсоналних божанстава на крају доживе као садржаји људске психе. Фон Францова (1997: 20) разјашњава да психа колективног несвесног задржава само оно релевантно за чланове заједнице, оно што их може на неки начин излечити кроз компензацију која балансира једностраност човекове девијантне природе.

Слично гледишту фон Францове, Нојман и Јунг (1989: xxiv) виде Его првобитно садржан у несвесном, а који стиче способност релативизовања сопственог искуства када постаје свестан свог положаја који властитом активношћу

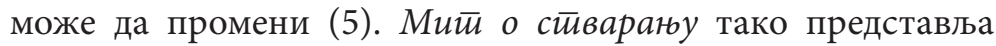
првобитни мит у коме свет и несвесно постају објекти мита чије фазе чине човеково рођење, патња и еманципација. Следи фаза одвајања од Родитеља света која је оличена у мит̄у о херојима. Фон Францова (1997: 13-14) констатује да је јунак најчешће млади принц или неко из нижих слојева друштва од кога се не очекује много. Такав јунак носи потенцијал да се уздигне на друштвеној лествици и тиме потврди значај саморазвоја. Нојман (1989: 5) изричито заступа виђење да је у почетку било савршенство целовитости које се опире неком прецизнијем опису од оног митског јер Его и тај почетак, који представљају оно што описује и оно што се описује, постају немерљиви оног тренутка када Его покуша да појмовно сагледа предмет свог посматрања. У праскозорју свог настанка психа је отворена ка свету и митолошке приче 
без изузетка морају кренути од спољашњег света јер свет и психа још увек нису издиференцирани. Овде још увек не постоји самосвесни Его и зато он сопствено постање схвата као постање света. Касирер (1985) је показао да се у свим религијама које је испитивао стварање приказује као стварање светлости, па се тако свесност поистовећује са светлошћу без које се не би могло сагледати нити једно дешавање у свету. Феноменом светлости без које нема погледа ни препознавања властите целовитости кроз одраз бавио се и Лакан (1986: 82) који каже да је функција погледа да помогне да се схвати шта је то најтананије што управља човеком. Он мисли да оно што устројава нашу свест јесте властита представа о томе да смо посматрана бића у позоришту света (83).

\section{1. Симболика круга и уроборос}

Још је у Тимају, дијалогу о настанку света, Платон (1981) сферу замишљао као најсавршенију фигуру коју је демијург изабрао да би по њој направио све. Нојман (1989: 8) прихвата да је круг један од симбола првобитног савршенства као језгро почетка, клица из које свет ниче, стање у коме су супротности обједињене или се још увек нису разјединиле. Са кругом су по овом моделу повезани сфера, јаје и ротунда која за Јунга (1980) представља апстрактну трансценденталну идеју. Приказујући круг као јединство супротности по угледу на симболичке односе белог и црног, дана и ноћи, неба и земље, мушког и женског, Нојман (1989: 9-10) доказује свеприсутност симболике круга у разним заједницама и раздобљима почевши од описа који је пружио Лао Це када говори о безобличном, али целовитом прапочетку који је непроменљив и не зависи ни од чега иако све испуњава и обухвата. Круг припада и индијској традицији која постулира првобитни стваралачки елемент као великог хермафродита чији се мушки и женски чиниоци касније раздвајају, а идеју хермафродитске, самодовољне природе прапочетка налазимо и у Платоновом виђењу прачовека. Древни египатски симбол змаја који гризе сопствени реп спада у ред приказивања животног циклуса у 
кружном облику, а сличан приказ божанске змије имали су и Вавилонци. Представа о уроборосу постоји у Откровењу светог Јована, у учењима гностика и код староримских синкретиста, а на тлу Северне Америке Индијанци племена Навахо су такође сликама илустровали сличне призоре.

На плану психе појединца, круг оличава стање најранијег детињства пре настанка свесности. Ово праисторијско стање постојања Нојман (12-13) објашњава концептима космичке вечности и бескраја које освешћени појединац поистовећује са периодом боравка у утроби мајке. Још је Фројд приметио да архетипске представе утробе обухватају просторе који имају неку шупљину или их карактерише дубина типа провалије, долине, морског дна, пећине и града, али Нојман (14) Фројду замера то што ове појмове није узимао за симболе. Фројд је тиме ограничио разумевање појмова на мали део широког опсега значења архетипа. Холбек (1987: 297) такође примећује да је Фројду било страно размишљање о биполарној природи архетипа: Холбек хвали јунгијанско инсистирање на постојању односа асоцијације, преклапања и мешања међу архетиповима чији се симболички израз може растумачити тек након холистичког приступа целини чији су они део.

За Фон Францову (1997: 38) круг је сличан симболу лопте која је људима фасцинантна по томе што има минимални контакт са земљом и по трајности покрета јер се може замислити њено кретање по благо косој површини скоро у недоглед. Поседујући тако особине неземаљског и перманентног, појам лопте има назнаке нечег божанског (39).

Бавећи се митом о Амору и Психи, Нојман (1971) тумачи појам женскости преко појмова свесности и одвајања од Мајке. Его у својој ембрионалној фази јесте инертан у својој ослоњености на Велику мајку и Нојману (1989: 15) та неодвојивост човека од Мајке служи као образац за човекову визију Раја коме ће човек увек тежити без шансе да га икада поново истински доживи. Его тако може да јача и властито постојање му не делује мучно и опресивно онда када постаје свестан стварности и сопствене различитости упркос томе што се примамљивост сна и даље опажа као пријатност. Нојман (17) упућује на стриктно симболичку природу 
уроборичког инцеста на овом ступњу где је акценат на задовољству и љубави који ни у ком смислу нису активни. Овде је пре реч о жељи за препуштањем првобитној целовитости и пуноћи којој је Јунг (1916) дао гностички назив йлерома, а која у светлу Јунговог хришћанског приступа означава божанску свеукупност: разноврсни облици носталгије и чежње представљају враћање уроборичком инцесту и посебно у германској романтичарској тенденцији ка растапању сопства, па симболи који упућују на уроборос могу бити и они који имају димензију подсећања на смрт и смртност, по моделу појмова земља, гроб, мртвачки сандук и урна. За Нојмана (1989: 18) уроборос може да подразумева и Родитеље света који исказују стање постојања трансценденталног и божанског које не зависи ни од каквих супротности, већ симболизује стваралачки импулс новог почетка. Та особина првобитног подстицаја одражава очинску, прокреативну страну за коју Нојман тврди да је теже замислити од оног мајчинског аспекта. Постојање прелаза од слике ка апстрактној идеји доказује се тиме што се староегипатски хијероглиф који значи мисао представља сликом за срие, а іовор се исказује хијероглифом који означава језик као део тела.

У делу Psychic Conflicts in a Child ${ }^{1}$ (1969) Јунг први пут примењује појам инйроверзије који обележава окретање либида субјекта ка својој унутрашњости. Према томе, самоиндукујуће дејство интроверзије узрокује настанак фундаменталног искуства духа који сам себе генерише и то се илуструје одломком из једног египатског текста који указује на Бога који је сам себе створио као првог од првих Богова. Из овога произилази да је живот настао као фузија живота и душе као живе психе која је снага и покрет, дах који улива живот. На овом месту се долази до улоге знања у стварању живота јер се издваја мотив океана који је истовремено симбол и уробороса створитеља и знања. Ово се образлаже учесталошћу појаве да јунаци раних култура, као што су вавилонска и грчка, израњају из мора и својим знањем доносе просвећеност свету. Нојман (1989: 23-24) пише да се у митовима за првобитно знање каже да је пренатално, да претходи постанку Ега и свесности, па је отуда

1 Дело је први пут објављено 1910. године. 
по митолошкој теорији укупно знање исто што и памћење, а ово исказује и Платонова филозофска доктрина о пренаталној визији идеја и сећању на њих.

Запажено је да нема мало примитивних култура у којима се одрасли према деци опходе са посебним поштовањем баш због скоро инстинктивног осећаја да деца поседују савршеност наслућених архетипских вредности. Колективно несвесно утврђује положај детета у заједници јер се за децу мисли да својим претпостављеним поновним рођењем преносе биолошко и културално искуство заједничких предака.

\subsection{1. Укорењеност у телесном}

Поједине групе симбола се доводе у везу са одређеним деловима људског тела, па се тако предео стомака поистовећује са нагонима, груди и срце са осећањима, а предео главе и мозга са духовним. Оваква шема тела је истоветна на свим континентима где постоји архетип по коме је читава слика света начињена по узору на људско тело. Разлог оваквом виђењу света Нојман (25-26) налази у страху примитивног човека од утицаја магије по коме сваки део тела представља целог човека који може бити омађијан ако се овлада макар неким његовим делом. Срце је средиште личности за примитивног човека, али и за народе индијске и хебрејске традиције, баш као што је за савременог човека то глава као оличење разума.

Нојман (27) позива да се већа пажња посвети проучавању висцералне психологије глади. Он наводи да су средњовековни уметници често посезали за употребом архетипа да се неко йроїyйа и йоjege у приказима пакла и ђавола, мада и у речнику савременог човека постоје фразе које алудирају на то да већи йрожgире мањег и да непожељне особине попут љубоморе или грамзивости могу да изјеgу човека. Представа о прождрљивости уробороса као змије која гута властити реп на овај начин алудира на смрт. На нивоу на коме се уроборос повезује са космогонијом, даје се пример прамисли у Индији где се свет или космички садржај значењски изједначавају са жртвеном храном која се приноси Богу који се слави као хранитељ и као субјекат који прождирући инкорпорира објекат 
који му повећава снагу (28-29). Овде је видљива материнска страна уробороса у односу мајка-дете у коме је свака потреба глад, а задовољење је ситост; стећи нешто значи јести, али не и оплодити (31). Телесне функције се ту опажају као психички процеси, усвајање и варење хране узрок су промени унутар човека и та промена подстакнута храњењем јесте и увек ће бити фундаментално искуство сваког човека јер, како тврде когнитивни структуралисти Лејкоф и Џонсон (2014: 244), све категорије које људи образују потичу из наше утеловљености.

Груди и дојење такође представљају генеративне елементе при чему је крава најчешћи симбол за дојиљу. Дојиља представља очински лик управо због прокреативног аспекта значења, док би одојче, било мушко или женско, својом рецептивном природом исказивало женскост. Фон Францова (1997: 57) у менталном склопу сваког људског бића и културе проналази сан о Рају као о прошлом, идеалном златном добу одсуства физичке патње који у пројектованој фантазији може постати будући циљ. Ауторка Рају приписује структуру мандале која има позитивни формативни и стабилизујући утицај на личност јер означава Его који се на путу свог развоја или индивидуације креће према себи уместо ка неком спољашњем предмету.

Циљ индивидуације је да човек постане независтан од света, да не допусти да га свет прогута тиме што ће му постати важнији од сопствене вредности: уроборос се смешта у средиште несвесног света примитивног човека и детета, али постаје и позитивни симбол тренда развоја који човека усмерава према зрелости. Нојман (37-38) у онтогенези види уроборос који испливава при крају живота када се наслућује неизбежни долазак растакања Ега, када принцип поновног рођења постаје креативни, а не регресивни, патолошки принцип који помаже човеку да превазиђе страх од смрти. По овоме закључујемо да је у религиозном и креативном смислу уроборос оличење регенеративног извора вишег живота.

Уроборос се у хришћанству обележава савршеном фигуром круга из чијег центра полазе четири крака који су оличење спокоја јединства супротности. Џоунс (Jones 1951) 
је мишљења да хришћанство није било у стању да интегрише основни породични систем мајке, оца и сина, те је решење пронађено у постојању Светог духа као треће појаве у Светом тројству. Увођење Светог духа Џоунс тумачи на основу покушаја да се доведе у питање очева улога у стварању новог живота, али и да се оповргне постојање родоскрвне жеље Сина. Син је истовремено тај који је благ и који опрашта, па преко ових црта женске нарави Џоунс оправдава своје виђење Исуса као андрогене појаве која је због тог замишљеног идеала блискости са оба родитеља постала привлачна и блиска припадницима оба пола. Џоунс овим упрошћавањем игнорише јунгијанско инсистирање на симболичкој природи човекових схватања.

\section{2. Симболичка вредност Велике мајке у фолклористици}

Јунгијанци сматрају да рођење маркира одвајање од уробороса и силазак у нижи свет стварности који обилује непријатностима и опасностима. Појединац стиче свест о амбивалентној природи односа задовољства и бола који потичу из непосредног човековог искуства које тешко да може да објасни откуд у природи толико бесмисленог разарања паралелно са, чини се, мноштвом инстинктивног стварања, па Нојман (39-40) претпоставља да човеков Его који се буди мора да доживљава свет као простор у коме влада ирационални хир матријархата са својим богињама материнства и судбине. Јунг (2015: 91-92) је убеђен да је архетип детерминисан тек када се садржај примордијалне слике испуни материјалом сопственог искуства и то илуструје најкарактеристичнијим примером архетипа мајке где су први по важности ликови властите мајке, бабе, сестре, а онда долазе они које назива мајкама у фиіурайивном смислу попут богиња, Мајке Божје, Девице или Софије. У примерима из митологије које Јунг наводи за варијације архетипа мајке, као што су лик девојке у миту о Деметри, мајке-љубавнице Кибеле, богиње судбине Мојре и женске утваре Лилит, промаља се Јунгова спознаја наглашавања споја опречности као важне 
одлике архетипа. Архетип уроборичке владајуће Мајке садржи обрисе двоструке нарави: оне прождрљиве која је злочеста богиња смрти, куге, глади, поплава, нагонских сила, заводљиве деструктивности привидне лепоте и оне дарежљиве која нуди приврженост, обиље животних радости, срећу и лепоту милости, искупљења и вере у нови живот. Јунг архетип ћудљиве мајке уочава у појмовима који изазивају страхопоштовање типа небеса, земље, Цркве, месеца, шупљих предмета и чак свега материјалног. За Нојмана (1989: 42) је страх сасвим природна појава у психологији детета и примитивног човека: њима влада исконски страх од надмоћнијих спољашњих претећих сила, па зато они анимистички доживљавају свет око себе. Иако здрав развој подразумева да се страх временом превазилази, страх и потреба да се он превазиђе дају подстрек не само развоју свести појединца, већ развоју културе, религије, уметности и науке. Бахофен (Bachofen 1926) описује доминацију уробороса у инфантилној фази која је пандан претпостављеном времену матријархата, при чему се реч фаза схвата као структурални слој, нипошто као историјска епоха. Слојеви овако осмишљене структуре ослањају се један на други по узору на модел геолошке стратификације где старији слојеви могу да избију на површину тако што ће на дно потиснути новије. Симбол Велике мајке Нојман (1989: 41-42) уочава у приказима мора, језера или река, док се дете представља као риба у тој води, чиме се истиче детиња беспомоћност и судбинска предодређеност да зависи од мајке, баш као на сликама Девице Марије која држи Исуса или у приказима богиње Изиде док оживљава сина Хоруса кога је претходно ујела шкорпија, животиња која буди асоцијације на међусобно супротстављена значења женскости. Нојман (45) уроборички карактер Велике мајке чита свуда где се она слави у андрогеној форми - попут брадате жене на Кипру и у Картагини.

Амбивалентност односа заштитнички настројене мајке и детета илуструје пример из грчке митологије који презентује Нојман (41-43): након што је на себе навукла гнев љубоморне богиње Хере јер је спасила Диониса, богиња Инона је кажњена лудилом и, по једној причи, она се баца са сином у море одакле их избавља бог Посејдон. Према другој причи, Инона је прво 
удавила дете у врелој води, па је са њим скочила у море. Случај богиње Иноне је симптоматичан јер поставља питање тумачења поруке мита. Не можемо да не приметимо да овде постоји континуитет јунгијанске школе у односу на Фројда (2013: 178180) који је, тумачећи рад сна, прихватио тврдњу неких истраживача да је у језицима и културама старих народа, као што су били древни Грци и Египћани, сасвим нормална појава да неки елементи истовремено носе супротстављена значења. Фројд ово извртање односа, ситуација и редоследа дешавања сматра архаичним и претпоставља оно што Јунг прихвата, а то је да у сновима и код примитивних људи ми не знамо да ли неки догађај носи позитиван или негативан предзнак. По овоме, Инонино лудило би могло бити оно што оправдава њене нечовечне поступке према сину, али тешко је одолети интерпретацији да митски приповедач показује разумевање за њу и награђује је избављењем у морској води.

Смрт и ускрснуће детета јесу стална места у овом култу који живи и у критској традицији у вези са Миносом, Зевсовим сином који се сваке године наново рађа у облику козе, краве, крмаче, голубице или пчеле. Јунг (2015: 92) сврстава ове и друге животиње које помажу човеку у категорију симбола одредитеља архетипа мајке, а у коме су средишње представе материце и свих ствари сличног облика. Дете које се жртвује у исто време зрачи светлошћу и његова смрт се не доживљава трагично, тај повратак Великој мајци означава налазак уточишта и треба да улије утеху. Нојман (1989: 45) користи Бахофенову синтагму йижан йо йрироgu да опише сваког од мајке рођеног јер свакога прати усуд пропадљивости и неизбежности смрти. Симболи који уроборички указују на тугу узроковану свешћу о смрти спрам рођења и живота, а која обавија Его адолесцента, јесу точак света, Сестре суђаје и разбој тихог, али сигурног протицања времена. Ако се упореди са претходном инфантилном фазом, лепота ове фазе се налази у томе што је Его стекао неки степен аутономије.

Још увек присутна неодељеност детета од Велике мајке избија на површину и кроз њен однос са сином-љубавником. Нојман (46-47) помиње ликове Адониса, Озириса, Тамуза и Атиса које мајка рађа, али њихова важнија одлика је то што 
постају љубавници својих мајки. Мајка воли, убија, сахрањује и жали свога сина који се поново рађа кроз њу, а син превазилази своје несвесно потврђујући своју мушкост која ипак нема очинске тенденције. Бахофен (1926) даје апсолутни примат принципу мајке у односу на секундарни принцип синова који су подређени, пролазни и смртни. Лик мајке кроз рођење сина на одређени начин поприма особине одлучности оца. Кибела је оличење овакве мајке јер је била љубоморна на то што се њен син Атис заљубио у нимфу, па је учинила да њен син полуди и сам себе кастрира. Јунг (2015: 93-96) пише да

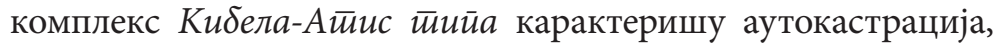
лудило и рана смрт детета, али више потенцира оно позитивно говорећи да код човека као што је Атис касније у животу може да се развије и здраво уобличи јак осећај за историју, конзервативизам и богатство религиозних осећања.

У старом граду Уру пронађене су неке од најстаријих представа култа Велике мајке на којима и мајка и дете имају змијске главе, па се изводи закључак да је змија најстарији уроборички облик Велике мајке. И дете је змија због своје везаности за мајку, али временом обоје попримају људски облик све док се потпуно не преобразе у Мајку Божју. Трансформација се одвија на такав начин да је глава онај део тела који последњи губи змијски облик. Сликама мајке и детета у којима се задржава једино људска форма претходе прикази мајке у људском облику чији је пратилац змија или фалус, али и ликови детета са великом змијом. Кирло (Cirlot 1971: 186) пише да је оваква подела присутна у вавилонском миту о месопотамијском Тиамату и о морском чудовишту Левијатану познатом и у Јеврејској Библији, а које се такође на крају дели на два дела. Новонастала фалусна божанства не репрезентују само плодност која ниче из земље, већ саму вегетацију: њихово постојање чини земљу плодном, али након што достигну зрелост, морају се убити и пожњети баш као сноп пшенице за који Нојман (1989: 49-51) подсећа да се често на сликама налази поред хришћанске Мадоне. Пшеница је архетип тела младог сина, бога принципа пролећа, који мора да се убије да би Мајка могла да га оплакује и да га поново роди. Свим љубавницима Велике мајке заједничко је то што 
су њихова лепота и љупкост упечатљиви колико и њихова нарцисоидност која се у митовима појављује у облику нежних цветова нарциса, јасмина или љубичице који се у доминантно патријархалној култури пре поистовећују са младим девојкама него са младићима. Велика мајка је очарана њиховом физичком лепотом и за разлику од митолошких ликова јунака, ови не поседују снагу, карактер, индивидуалност ни иницијативу - у сваком смислу је изражена нарцистичка опседнутост сопственом телесном привлачношћу. Тек касније секундарном персонализацијом сам бог коме фалус припада постаје важан и онда настају митови у вези са људским бићима - тада настају приче о смртницима који имају авантуре и романсе са боговима и богињама. Млади бог се нарцистички идентификује са својим телом мушкарца и фалусом као његовим дистинктивним обележјем, судбина оваквих мушкараца је колективна и ритуалног је карактера, њихова слабост их онемогућава да имају појединачно постојање као личност. Ово такође значи да Велика мајка нема однос са појединцем, већ са младићем као архетипским ликом. Настојање Ега да се отргне од доминације несвесног приказано је у миту о Нарцису у коме је фасцинација собом натерала Нарциса да испуни своју архетипску фаталну судбину. Посматрајући самог себе, Нарцис подлеже погубним чарима самољубља које растапа свесни део његовог Ега и води га у дављеничку смрт (96). Лаш (Lasch 1986: 42) порекло нарцистичких склоности налази управо у оралном лишавању из преедипалне фазе. Он каже да нарцис бира самоочување уместо самоусавршавања (60), врло негативно карактерише нарцизам када каже да је то пре мржња према себи него дивљење себи (36), па констатује и да је нарцису преко потребно одобравање других да би учврстио осећај сопства (23).

Хардингова (2017), први значајнији јунгијански аналитичар из САД-а, појашњава да је Велика мајка девица у смислу њене плодности јер не зависи ни од ког мушкарца. Хардингова каже да ово гледиште потврђује санскрит у

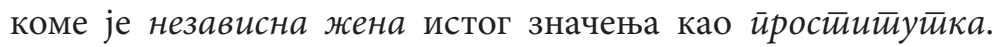
Амазонка је неспутана у својој независности потпуно исто као и жена која представља плодност земље - мушкарац је 
за њу, мајку свега што се рађа, само пролазно и заменљиво средство анонимне моћи за остварење циља. Кастрација као претња јесте смртоносна и долази са појавом Велике мајке за коју су вољење, умирање и одузимање мушкости једно исто. Нојман (1989: 53) овде не одустаје од схватања кастрације као симболичког и трансперсоналног, никако личног чина, а овај аргумент се потврђује тиме што у каснијим временима једино свештеници бивају поштеђени смрти од стране Велике мајке јер су се симболички њој већ добровољно предали.

Кључну особину женског елемента под утицајем Велике мајке представља њена фасцинираност негативним. Одраз овога уочавамо у њеној дивљачкој природи и магијским вештичјим моћима. Она се узима за богињу прогона, рата, њени ритуали су пуни крви, прославе наликују оргијама које су увек прожете тоном смрти. Људске жртве које се приносе ради плодности познате су широм света и свуда крв има главну улогу у обредима плодности и жртвовању људи, па изгледа да су људи прилично рано прихватили земаљски закон да нема живота ни плодности без претходне смрти и жртвовања. Судећи по јеврејским легендама и индијској традицији, Нојман (55-56) претпоставља да су људи по свој прилици повезали крв и плодност са изостанком менструалног крварења код жене током трудноће, те се проливање крви, људске или животињске, препознаје као свети чин.

Мит о Озирису и Изиди поседује главне одлике архетипа о Страшној мајци и њеном сину. Ликови ових митова се спајају са својом анимом или анимусом, одразом властите душе јунака у слици особе супротног пола који чини суштину за изградњу става према особама супротног пола. Јунг (2005: 28) у аними и анимусу назире недозрелост, извесни инфериорни однос према окружењу или жељи. Логичним се чини да је Јунг (2015: 65-66) принцип анимуса и аниме преузео из области феноменологије, па се ова два појма структуралистички дају разумети на основу система бинарних опозиција у коме је прва дистинктивна подела на мушко и женско. Изида, Нефтида, Сет и Озирис су сестре и браћа од којих Изида и Озирис још у утроби мајке нагињу једно ка другом. Прича о развоју њихових односа доказује колико је била велика потреба древних 
људи да јасно дефинишу односе и поставе границе међу члановима породице, а то је заправо питање значења индивидуације. Изида је сестра и жена која поседује нешто магијско у ставу према Озирису, док се у завршној фази мита она удаљава од свог карактера Велике мајке и постаје позитивни симбол материнске и супружничке љубави. Када Озириса убија брат и непријатељ Сет, Изида је та која попут мајке омогућава поновно рођење свом брату-мужу. Било је неопходно да „добра” Изида одустане од своје матријархалне надмоћи која изгледа да је била присутна у првобитној владавини египатских краљица. Mope (Moret 1927: 96) истиче да је прелаз ка патријархалном систему оличен у Изидином настојању да богови признају легитимитет њеног сина Хоруса не преко њене, мајчине линије, већ преко његовог оца Озириса. Тако од Озириса почиње традиција да син наслеђује оца фараона од којих сваки носи титулу Син Хоруса. Да би Хорус стекао своју зрелост, било је неопходно да се у њему пробуди бунт уперен против мајке који је кулминирао тиме што јој је одрубио главу која јој је чинима бога Тота накнадно враћена.

Фон Францова (1997: 37) изричито каже да издизање у ваздух, које повезујемо са птицама, увек денотира продуховљење. Велика мајка је у критско-микенској култури богиња природе, а њен заштитни знак је голубица која касније представља Афродиту и Марију кроз голубицу Светог духа. Клањали су јој се у пећинама и, судећи по крзненим одевним предметима који су се носили у ритуалима, овај култ потиче из каменог доба. Симболика птице се може представити по обрасцу Лефлер-Делашоове (Loeffler-Delachaux 1949) која разликује три нивоа значења у бајкама, митовима и јуначким еповима: голубица као симбол на профаном нивоу означава сексуалну љубав и нежност физичког додира, на нивоу светог гавран симболизује заштиту и добру намеру према другима, а феникс алудира на реинкарнацију и бесмртност.

Кадмо је утемељитељ Тебе и његове ћерке су испољавале опакост природе Велике мајке. Једна од његових ћерки је Семела, Дионисова мајка и Зевсова љубавница коју убија његов гром, друга ћерка је Инона која се у нападу лудила баца у море са сином-љубавником Меликертом. Трећа Кадмова 
ћерка је Агава која у бесу оргија убија, растргне и тријумфално проноси главу сина Пентеја који тако постаје дионизијски симбол кастрираног бога. Аутоноја је четврта ћерка чији је син Актеон ловац кога сопствени пси растргну након што се од страха претвори у срндаћа јер је властитом необазривошћу видео нагу Артемиду која је богиња шума, а што је чини представницом Велике мајке у Беотији. Примећујемо да се ликови Кадмових ћерки постепено удаљавају од свемоћног појма женскости јер оне су те које може да савлада Зевс као мушки принцип сунца или које страдају од сопственог лудила. Њихови синови такође суморно завршавају, али не више као пуке немоћне жртве - у лику Актеона назиру се црте стида који је почетак освешћивања мушке снаге (81).

Кадмов једини син је Полидор који је деда краља Лаја, а његов потомак је Едип са којим коначно долази до раскида кобне везе између Велике мајке и сина-љубавника. Прекид са старом традицијом наступа и са Хипермнестром која одбија да убије свога мужа, те овим чином љубавни однос у митологији постаје ствар личног избора. Она укида негативни утицај Велике мајке и тако омогућава да се потом јављају јунаци попут Персеја и Херкула којима је заједничко то што покоравају симболе матријархалне доминације.

Представе Велике мајке као крмаче концептуализују схватање ње као монструозног женског идола још из доба неолита. Смит (Smith 1919: 216) каже да је у Троји откривена фигура свиње окружене звездама која очигледно представља мајку-богињу као крмачу, а Нојман (1989: 84-85) сведочи о бројним траговима овог култа - од приказа богиње Изиде како јаше свињу до слике краља Миноса кога доји крмача. Нојман незнању приписује сиријска тумачења крмаче као симбола нечистог, али ми ту проналазимо кохерентност из визуре јунгијанског дуалног принципа по коме су екстремне појаве суштински блиске. Обожавање свиње узима се као део култа бога Адониса и њена светост се потврђује феничанским обичајем да се свиња жртвује при обреду слављења смрти овог бога, али и такође феничанским обичајем да се не једе свињетина. Фрејзер (Frazer 1951: 546) показује да се богови Атис, Адонис и Озирис идентификују са свињом, па се долази 
до закључка да је у свим заједницама где је забрањено да се једе свињско месо и где год се свиња сматра нечистом сасвим извесно да је свиња имала карактер светости. Поштовање свињи одала је Елеусина постављањем лика свиње на своје прве новчиће, а организовале су се и прославе у част богиње Афродите којој се жртвује свиња и где се људи пресвлаче у одећу припадника супротног пола. Мора да се ове прославе нису много разликовале од увреженог схватања баханалија будући да Нојман (1989: 86) Афродитином лику у својој првобитној појавности као Велике мајке приписује иницирање луgила афродизије. Сличне хибридне спојеве грозног женског и фалусних симбола налазимо код описа Медузе са змијама уместо косе, отворених уста, са вепровим кљовама, који евоцирају кастрирајуће чељусти пакла. Паук припада овој групи симбола јер женка прождире мужјака након односа, али и зато што се сматра да је у женској природи да плете мрежу за неспремног мужјака (87). Плетење наглашава замршеност женског карактера посматраног из мушког угла, па тако Сестре суђаје преду плетиво живота и нордијске Норне плету мрежу света у коме је запетљан сваки човек рођен од жене.

Развојем самосвести и патријархалног устројства друштва долази до расцепа у поимању Велике мајке чији се једино позитивни аспекти задржавају у свести и временом стичу људски облик, док се застрашујући елементи потискују у несвесно. Бетелхајм (1979: 80-83) говори о овом расцепу као последици неспремности да се прихвати фрустрирајућа страна промене у омиљеном лику. Ова рационализација настаје јер особа још увек није способна да сагледа сагласност различитих појава са више страна, већ жели да очува идеалну слику вољеног бића које је на неки начин ускратило благонаклоност, па се тако у причама јављају парови типа добре мајке и зле маћехе.

Нојман (1989: 94) пише да се грозоморне особине Велике мајке приписују некој животињи као што је то случај са медведом, честим архетипом у Азији и Европи који се поистовећује са Кибелом. Значај култа медведа изражен је у астрологији где читаво сазвежђе носи назив Велики медвед. Бахофен (1926) примећује да развитком култа оца долази до замене фигуре медведа фигуром лава јер је очигледнија 
разлика између лава и лавице него између медведа и мечке. Бетелхајм (1979: 75) објашњава значај ове ексииернализације, тј. преноса људских особина на животиње, потребом ума примитивног човека да на основу познатих представа фантазијом попуњава шупљине у поимању.

Мотив близанаца Нојман (1989: 97) узима као преломни чинилац у египатском миту о Озирису и Сету чији је ехо у модерној причи Р. Л. Стивенсона о Џекилу и Хајду, у хананској митологији где се очитава у борби између Бала и Мота и у библијској причи о Јакову и Исаву. Психолошки развој одговара промени првобитног ритуала плодности који чини позадину ових прича. У почетку су убијали младог краља плодности, његово тело би раскомадали и бацали по пољима. Женска представница Велике богиње је такође са њим жртвована. Настанак божанства мајке вероватно уноси новину тиме што се њена представница не убија како би се славио годишњи брак са младим краљем. Изгледа да је након тога чин жртвовања замењен борбом краља са себи донекле равним претендентом на престо. Губитник из ове борбе би био жртвован у име старе године. Изгледа да се обичај убијања краља касније изгубио јер су се животиње жртвовале уместо људи и то личи на последицу усмерености ка апстрактнијем, симболичком размишљању.

Финална фаза борбе између свести Ега и несвесног подразумева свођење женског на пуко средство за рађање док мушко само себе изнова рађа. Међутим, током прелазног периода креативна моћ мајке и њена регенеративна снага настављају да постоје паралелно са мушким принципом заједно градећи целину и јединство при чему суштина мушког принципа не бива промењена од стране женског. Утисак је да је та издржљивост мушког аналогију пронашла у неуништивости мале кости луи из јеврејске легенде о кости седалног дела кичме јунака. Нојман (100) каже да химне из Ригведа сведоче управо о томе - да смрт није крај, већ прелаз и уточиште. Его који постаје све зрелији има све израженију жељу за новим животом после смрти, тако смртност појединца није једини аспект живота и не остварује се само у старој поставци односа младог љубавника и Велике мајке. 
Мушки принцип је довољно ојачао да досеже ниво на коме поседује свест о себи, он више није син сателит уроборичке мајке прикован за свемоћно несвесно, он је постао истински независтан и способан да стоји сам.

\section{4. Закључак}

Јунгијанска психоаналитичари настоје да се одмакну од Фројдовог свођења суштине човека на пуки механицизам нагонских сила и проучавају општије идеје које не занемарују, али превазилазе свет чулно опипљивог. У симболичности лоцирамо срж јунгијанске парадигме размишљања јер је симбол увек производ друштвеног договора, Одгонетање принципа употребе симбола у онтогенетском и филогенетском развоју човека мора ићи преко анализирања његове интеракције са правилима заједнице којој припада, а која су отелотворена у устаљеним фолклорним обичајима. Упечатљива сличност архетипских представа присутних код различитих народа може се објаснити појавом преузимања прича од оних са којима су долазили у контакт и са којима су се могли идентификовати, али и базичном истоветношћу људске природе. У приказима древних народа може се назрети да се човекови почеци препознају као уроњеност у неиздиференцираност уроборичког круга колективног несвесног које подсећа на идеализовану лагодност пренаталног боравка у утроби мајке. Сазревање се схвата као индивидуација - процес дефинисања себе кроз окретање ка властитом унутарњем сопству издвајањем из океана претходности који у фолклору осликава фигура Велике мајке која протоком времена стиче карактеристике амбиваленције: На путу јачања сопственог интегритета и згушњавања властитог Ја човек мора освестити и превазићи болне сусрете са својом тамнијом нагонском страном, мора прихватити своју аниму или анимуса, заузети оптималну дистанцу према ономе чему је некада апсолутно безболно припадао, а што се временом мења.

Приче о егоцентричним мајкама и љубавницама из митологије тестирају и упозоравају колико је важно 
одупрети се властитој егоманији и тежити да се успоставе јасни односи са људима из окружења који су одраз наше личности јер те релације моделују све будуће везе са људима. Јунгијанци оправдавају да се у фолклорним наративима ментална слика особе према којој се гаје помешана осећања трансформише, чак расцепи на ентитете ради бољег прихватања и савладавања препрека ка циљу самоостварења и тиме се показује како народна традиција ненаметљиво сугерише могућа решења кризних животних ситуација.

\section{Извори и литература}

Bachofen, Johann J. Urreligion und antike Symbole. Leipzig: P. Reclamjun, 1926. Штампано.

Beit, Hedwig von. Symbolik des Märchens. Bern: A. Francke, 1956. Штампано.

Бетелхајм, Бруно. Значење бајки. Београд: Просвета, 1979. Штампано.

Dundes, Alan. The Meaning of Folklore. Logan: Utah State University, 2007. Штампано.

Jacobi, Jolande. Complex, Archetype and Symbol in the Psychology of C.G. Jung. New York: Princeton, 1959. Штампано.

Jones, Ernest. Psychoanalysis and the Christian Religion. Essays in Applied Psychoanalysis. London: The Hogarth Press and the Institute of Psychoanalysis, 1951. Штампано.

Јунг, Карл Густав. Архетипови и колективно несвесно. Београд: Народна књига и Миба Боокс, 2015. Штампано.

Jung, Carl Gustav. Psychic Conflicts in a Child. New York: Princeton University Press, 1969. Штампано.

Jung, Carl Gustav. Psychological Types. Eastford: Martino Fine Books, 2016. Штампано.

Jung, Carl Gustav. Psychology and Alchemy. U Collected Works of C. G. Jung. London: Routledge, 1980. Штампано.

Jung, Carl Gustav. The Seven Sermons to the Dead. 1916. (12. mart 2018) <http://gnosis.org/library/7Sermons.htm>

Јунг, Карл Густав. Човек и његови симболи. Земун: Народна књига и Алфа, 2005. Штампано.

Касирер, Ернст. Филозофија симболичких облика. Нови Сад: Къижевна заједница Нови Сад, 1985. Штампано. 
Lasch, Christopher. Narcistička kultura. Zagreb: Naprijed, 1986. Штампано.

Lacan, Jacques. Četiri temeljna pojma psihoanalize. Zagreb: Naprijed, 1986. Штампано.

Лејкоф, Џорџ. \& Марк Џонсон. Утеловљени ум. Језик и сазнање - хрестоматија из когнитивне лингвистике. Београд: Чигоја штампа, 2014. Штампано.

Loeffler-Delachaux, Marguerite. Le Symbolisme des contes de $f$ ées. Paris: L'Arche, 1949. Штампано.

Moret, Alexander. The Nile and Egyptian Civilisation. London: K. Paul, Trench, Trubner \& Co, 1927. Штампано.

Neumann, Erich. Amor and Psyche. New York: Princeton University Press, 1971. Штампано.

Neumann, Erich \& Jung Carl Gustav. The Origins and History of Consciousness. London: Karnac Books, 1989. Штампано.

Платон. Тимај. Загреб: Младост, 1981. Штампано.

Smith, Grafton E. The Evolution of the Dragon. Manchester: The University Press, 1919. Штампано.

Franz, Marie-Louise von. Archetypal Patterns in Fairy Tales. Toronto: Inner City Books, 1997. Штампано.

Franz, Marie-Louise von. On Divination and Synchronicity. Toronto: Inner City Books, 1980. Штампано.

Франц, Мари-Луиз. фон. Алхемија - увод у симболизам и психологију. Београд: Атос, 2011. Штампано.

Frazer, James. The Golden Bough. New York: The Macmillan Company, 1951. Штампано.

Фројд, Сигмунд. Увод у психоанализу. Београд: Невен, 2013. Штампано.

Harding, M. Esther. Woman's Mysteries: Ancient and Modern. Boulder: Shambhala, 2017. Штампано.

Holbek, Bengt. Interpretation of Fairy Tales - Danish Folklore in a European Perspective. Helsinki: Academia Scientiarium Fennica, 1987. Штампано.

Cirlot, Juan E. A Dictionary of Symbols. New York: Dorset Press, 1971. Штампано.

Clough, William R. Reflections on Psychology, Culture and Life. 2013. (14. april 2018) <http://www.cgjungpage.org/learn/articles/analytical-psychology/89-jung-and-philosophy?start=1>

Wehr, Gerhard. Jung: A Biography. Boston/Shaftesbury, Dorset: Shambhala, 1987. Штампано. 


\section{Sanja Korićanac}

\section{JUNGIAN PSYCHOANALYSIS IN FOLKLORE STUDIES: MOTIFS OF OUROBOROS AND GREAT MOTHER}

\section{Resume}

Folklore can offer the contents of great interest to the Jungian psychoanalyst researchers since they may find there quite a few evidences that could help them support the theories on the continuum and universality of human nature both ontogenetically and phylogenetically. We have endeavoured to see through the motifs of Great Mother and ouroboros using the basic postulates and approaches of the representatives of this school of thought interpreting certain myths, folk tales and images in the function of one's personal development employing the crucial concepts defining the studies of Carl Gustav Jung, those being: personal and collective unconscious, transpersonal, symbolism, archetypes, synchronicity, duality, anima and animus, individuation, introversion, extroversion and centroversion. An attempt has been made so as to clarify why and how Jung and his followers proclaimed the motifs of Great Mother and ouroboros from folklore narrative as the elements relevant to the formation of consciousness of a mature individual in terms of being a community member.

Key Words: Jung, psychoanalysis, the Great Mother, uroboros, folklore, unconscious, symbolism, transpersonal, individuation. 